\title{
Changing Face of Motherhood Ideology
}

\author{
Umut Belek Erşen
}

Independent Researcher, Turkey

Copyright $(2016$ by authors, all rights reserved. Authors agree that this article remains permanently open access under the terms of the Creative Commons Attribution License 4.0 International License

\begin{abstract}
With influence of feminist movement, women came out of their own houses and built up their careers by working two times more than men. The matter of having a child that was pushed into the background has come to the fore in their mid-30s. Working women, as mothers at the same time, tried to fulfil their two times more responsibilities. Superpower mothers come into pieces among the descriptions of working woman, housewife and mothers, because equal relations cannot be structured in public domains and also existence of the roles based on traditional gender patterns continues at home. These super women have not been supported by both government and their husbands in this process. Thus, women started to leave most ignorable area gradually and turned towards the home and their children. Today motherhood ideology is more powerful than the past. Mothers consider "Motherhood" as the meaning of life and realize themselves through motherhood. Today motherhood's becoming more common with more extended limits results from unlimited realm of existence provided by motherhood. Can women build their careers and have children in the meanwhile? Or can't they complete their existences and do they have hope for traditional roles?
\end{abstract}

Keywords Motherhood, Ideology, Women

\section{Introduction}

Women's struggle for equal rights since 18th century has changed the form of various roles of femininity but it couldn't prevent the ossification of some of the tasks of women and burden new ones instead. Today, women work, meet the requirements of social and economic life and also they continue to do their traditional duties.

Women do not describe their issues as "problems". Acceptance and subjection are becoming general women behavior and stereotypes of the female roles remain present. Women can work, own a property and vote, but on the other hand they remain silent about the areas which they would protest, struggle and transform. Thus, women look after children and cook while men continue to be the master of the house. As Marilyn French pointed out, the problem boils down to the question of "who washes the dishes?"(1)

Gosta Esping Andersen describes the struggle for gender equality and equal access to the rights of women as "Unfinished Revolution". Andersen, in her research which is based on quantitative techniques, states that although there are some relative improvements in the status of women, the traditional gender roles seems to remain entirely the same. It is obvious especially at the division of household tasks, the working life and the decisions about marriage. The same point is also observed in the expression of the lives of women within the family. Traditional family-oriented woman, clearly and strongly maintain the validity at today's contemporary societies. (2)

In this context, one hand the motherhood is changing and becoming diverse, but this change is nothing but a key role in ensuring the continuity of status quo required by patriarchy. In this article, I will try to argue how motherhood ideology is re-established, by exploring the concept of ideology by Louis Althusser and how this ideology legitimize and provide to its continuity, by analyzing the concept of symbolic violence and masculine domination by Pierre Bourdieu.

\section{How Motherhood Changes?}

It's possible to observe the changes on the concept of motherhood by starting from the most outstanding areas of daily life. When you look at the magazines, you can see that models, actress and show business celebrities are either pregnant or they pose with their new born babies. If a newspaper or magazines publish a photograph of a model or actress, they always mention how many children she has. While in 90's, having a child is thrown out of focus, often an unspecified situation, nowadays it is rather highlighted. Those who do not have child think of having one or love children in front of media. Adriana Lima gives birth to her second child, Alessandra Ambrosio shows off with her happy family portrait in everywhere. What's going on? Do women both have a child and pursue their career or do not realize their existence and hope for help from the traditional ideology of feminity? 
As a matter of fact, this situation did not occur suddenly but has taken shape in a long process. With the impact of the feminist movement which gained momentum in the 80 's, women wanted to get out of the house and make a career; they worked twice as much as men and finishing only college was not enough so they had to have a Master or $\mathrm{PhD}$ degrees. They tried to deal with the dominant patriarchal values; sometimes they embraced those values in order to get involved in the business world and got used to them. In the meantime, the idea of having child was thrown away. Nevertheless, when they approached to mid-30's, they began to think of having a child. From the pure and childish voice of Nil, a famous Turkish pop singer, the song "I will both have a child and make a career" began to play but the reality did not had the same softness. Aside from the shortness of unpaid time-off, most of the time, they do not make use of this time-off. The actual lyrics of the song became "I milk, have a meeting with the customer, take care of the baby until morning, feed the baby and leave him/her to the babysitter, put on a make-up and run to my job". This does not sound that nice, doesn't it? Moreover, in the midst of such a rush, it is almost impossible to take a leave for the child in case of illness and the father has probably already been an important meeting. If a working mother takes much time off, then everybody starts talking like: "women always take a time-off when they have a child!"

Equal relationship-based structures could not be established in the public area. At home, the distribution patterns of gender roles exist somehow. So super power moms are divided in three, as business woman at job, a housewife at the home and self-sacrificing mother beside her child. Moreover, neither the state (time-offs, nursery, nursing home, etc.) nor their employees, nor their husband did not support them. In addition, the expenses of the house increases because of the cost of the baby like nursery. Thus, they gradually leave one of these areas which are the most dispensable, and devote themselves to home and her child.

Meanwhile, with the Queer movement spreading all over the world, gay marriages and non-married relationships have become more common and thus the family concept has begun to change shape. But at the same time, conservative values and administrations gained power and the importance of family, once again, started to be emphasized. For example, in Turkey under the ruling party AKP administration, all these developments took place as a phenomenon, and became one of the main factors in the process. Ideology of motherhood is more powerful than ever. So, how was this ideology re-established?

\section{Theory}

\subsection{Louis Althusser-İdeology}

According to Louis Althusser (7), ideology is not a system of ideas which are imposed one class to another, but rather the sum of all prevailing practices. It is on every part of life. Ideology hails or interpellates individuals as subjects. Individuals are named ideologically by the process of "interpellation". After that, all the relationships are interpreted by the subject under the impacts of and from the point of view of this naming. When each object is transformed to subject, it becomes a voluntary being for the sake of ensuring continuity. An individual becoming subject embraces the interpellation which gave him/her this qualification and in this way, individuals play their required social roles within the boundaries of becoming a subject. With interpellation, which is an important part of dominant ideology, along with traditions, customs and religious rules, women define themselves mother and become a player who maintain the dominant ideology, using the main discourse of that ideology such as "When I saw my baby I have a crash on her/him, there becomes an aureoia on my head, there was an sacred moment, that's the moment I felt in love my baby". No one talks about blood, tear, pain and puke.

According to Althusser (7), ideology never says "I'm ideology", but the dominant ideology bring the individuals under control using methods such as hailing, interpellation, and benefiting the power of certain tools like school, church, mosque, mass media etc. However, individual does not feel uncomfortable with this situation, and even she/he is happy with it. Because individual does not have the possibility to compare the ideological environment in which he lives, exists and surrounded by, with any alternative environments. After all, according to the majority of society, there isn't any other ideological environment.

The double mirror feature of the ideology ensures the following simultaneously:

1) Interpellation of individuals as subjects

2) The mutual recognition of subjects and Subject, the subject' recognition of each other and finally the subject's recognition of himself.

3) The absolute guarantee that everything really is so, and that on condition that the subjects recognize what they are and behave accordingly, everything will be all right.

As a result, surrounded by this threefold system of interpellation, universal recognition, and absolute guarantee, the subjects "work"; in other words, they accept the things as they are. They "work" by accepting the fact that everything is alright as it is.

This construction which Althusser established manifests itself in all the structures from women's practices of everyday life to basic principles which shape the lives of women. Interpellation of individuals as a subject can be observed in the way how women define themselves with motherhood. Women establish their life through motherhood and realize themselves through their children. Today the reproduction of the concept of motherhood is more widespread and inclusive as compared to the past, whereby it 
provides women an unlimited space for existence. Structure of ideology ensures that woman "work" as a wife and mother. Women, by being a mother, acquire a subject status and thus are accepted by the society. Ideological state apparatuses enable this process. The reproduction of ideology starts from the moment you step outside in the morning, -even at homeand continues throughout the day by various institutions which being interactioned. (from presentation of the news at T.V. and newspapers to relationships at office.)

According to Althusser (6), the main role of social institutions is to equip subjects with the forms of consciousness which are compulsory for undertake functions or duties of production in society. You could resist but you are not allowed to exit out of the current ideology. That a woman has no children is regarded as an abnormality that requires questioning. Not having a baby and escaping norms are not acceptable. While no one asks a mother why she is a mother and requires valid reasons for it, childless women are constantly asked to explain why they don't have a child. In contrast, woman who does not want to have a baby has a very little chance to escape from complaints of her mother and father (because they want to be grand mom and dad), incomprehension of her friends (because they want her to behave like themselves) and society and government promoting pregnancy and has different kinds of instruments to punish individuals who are not obeying social norms. (4)

With variety of role models, women are repeatedly reminded of that the only possible way to realize themselves and gain their subject status is to be mother. Beautiful mothers posing with their babies are taken part on photo galleries of newspapers, mother's fashion are described in details and baby-blog writers are everywhere on magazines, newspapers, TV and internet. Demi Moore -maybe the first example of today's "Beautiful Mother"- posed nude while she was pregnant many years ago and it created a great sensation those days. That the motherhood was involved on this kind of photo which focused on femininity and nudity was criticized. On the other hand due to the fact that she showed pregnancy as a natural part of feminity, she was also appreciated. Nowadays, magazines and newspapers are full of attractive pregnant women wearing a bikini with their fat bellies. Unlike in the past, while pregnant women prefer loose clothing to store their bellies, they are now wearing slinky dresses, t-shirts and emphasizing their bellies. While the acceptance of the fact that pregnancy and motherhood is natural part of feminity is a positive development, this time it has become a phenomenon which takes precedence over identity. Women are trying to get pregnant therefore they pay great amounts of money to IVF (in vitro fertilization) each year. Women do not question the fact that if they are ready to motherhood or not, they only think of getting pregnant as soon as possible to take a place beside beautiful mothers.

\subsection{Pierre Bourdieu-Masculine Domination}

Bourdieu's concepts of "Symbolic Violence" and
"Masculine Domination" help us understand how women take part automatically in this ideology and how they maintain the continuity of this structure. Manner of imposition of masculine domination and obedience to him is an excellent example of the relationship between dominant and dominated. Masculine Domination, in the most general sense, is a concept which suggests that inequality at the relationship between men and women is consistently reproduced. Bourdieu tackles how a form of domination which is established socially and historically, is eternalized, naturalized and internalized. Bourdieu's main concern is to reveal any effect which naturalizes unequal relations between genders and to show how these effects are built on the social foundations.(5)

Masculine domination use violence to sustain and to legitimize itself, like all the powers. Symbolic violence emerges precisely here. According to Bourdieu, symbolic violence is an invisible and polite form of violence. Symbolic violence continues to exist without counting it as violence because it is considered legitimate. Bourdieu explained symbolic violence like this: "It is never perceived as violence; it can be said that symbolic violence is preferred rather than being exposed to physical violence, such as exerting influence, confidence, personal dependency, hospitality, gift, strength of gratefulness and mercy."(6)

Masculine domination takes its power from the fact that the women accept this domination as legitimate and natural. In other words, women consent their subjection, not consciously but without coercion. With symbolic violence and power, masculine domination is maintained by women. The symbolic use of violence to women is always carried out by the imposition of a particular image and personality. It's expected that a woman should be friendly, obedient, cheerful and attractive. It is accepted that conditions of feminity are women's tolerance, her subordination and being dependent to men's expectations. According to this, women should be dependent to someone to create her personality and her life. Moreover, symbolic violence gives women a feeling of worthlessness and inadequacy through ordinary and natural practices of everyday life. In this way, women think that they need man in order to cope with these feelings and realize their existence. So under masculine domination, they try to accomplish man ideal, which is defined with virginity and beauty and again try to protect their symbolic value by improving their physical charm using cosmetic materials.(5)

Now women need motherhood in order to escape this feeling of worthlessness. In addition, their symbolic value no longer consists of only attraction and virginity. Women should be beautiful, well groomed, self-sacrificing mother and they should prioritize their children and babies. If women want to be seen, no matter how hard it is, she should provide these requirements. That's why, women always talk about magical aspects of motherhood, but a few tell the sleepless nights, postpartum depressions or sometimes women's regret of being mother. Continuity of motherhood ideal is compulsory, mothers legalize and internalize this and 
to provide also continuity of their existence protect this motherhood construct-discourse and spread with their own consent.

\section{Different Factors Affect the New Motherhood}

There are different elements play important roles on the re-establishment of masculine domination with using symbolic power which cannot be defined as violence. A new feminism (ecofeminism) and naturalism present new areas in which women can overcome the feeling of worthlessness and re-identify themselves. Guilt, maternal softness and mercy are used as a symbolic violence to make women embrace these areas.

Naturalism has re-emerged after the economic crisis busted out one after the other. In the first phase, women, as always, have been dismissed, most of them returned to homes, other ones have grew resentment and hatred against companies which could throw them out depending on whether the market conditions are good or bad. Women were the first to respond to the voice of naturalism because business world has created frustration on them, women were not been promoted, they did not obtain neither financial freedom nor social status what they hoped for.(4) As I mentioned before, they abandoned the expectations from work. The idea that the status of motherhood has its own value and raising a child may be their own masterpieces, has been once again emphasized. Unlike their mothers who tried to establish a balance between professional and family requirements, women are introduced to a new motto: children are first. Natural and biological laws, which always impose on women more important tasks about the child and maternal instinct, have been often emphasized and women have been accused of not listening to the voice of nature.

In the meantime, a new thought has emerged which argues that feminist movement has failed to provide equality between the men and women because differences between genders have not been considered. According to this view, women deny the essence of femininity in order to be equal with men and they have just been a copy of men. However, on the contrary, women should demand the natural differences as a right and convert this difference to a political moral weapon. Thus, a new feminism that reveals every aspect of women's biological experience was born. In this way, support for the consecration of motherhood was naturally given. (4)

All of these developments enabled the conversion of masculine domination, but maintained the codes which were embedded on the core. Increasing importance of breastfeeding is the most important factor to ensure re-domination process. Breastfeeding supporters asserted various economy and ecology-based arguments such as: Feeding with formula has high costs while breastfeeding has a lot of ecological benefits. Moreover, dangerous chemicals are used in the material of baby bottles. Result is obvious: Good mother is breastfeeding mother. A war has started against baby bottles, formulas, and kindergartens and, as a result, against working mothers. The best solution for the mother and child is the return of woman to the house. The motherhood should be granted value in order to convince women to these ideas. Every breast-feeding mother is a player of social change, is there any other mission more important, urgent and sacred than that? Women who do not act and feel this way, inevitable feel guilty. Mothers who prefer to bottle-feed and who cannot feel the same physical attachment to their babies are condemned. As a result, all mothers can breastfeed; there is no insurmountable difficulty for this. There cannot be different views on motherhood; ones who resist to these ideas are bad and insensible mothers. (4)

The fact that father is excluded from baby care process is another result of this glorification of breastfeeding. Thus, patriarchal model of couple has revived, at the same time -after twenty years of feminist struggle- the fact that new born babies are not keen on their father is suddenly legitimized for fathers. Baby care becomes an issue which is attributed only to mothers again, and fathers have reached a clear conscience to continue his work.

Nowadays, besides being a devoted mother, women have to be their child's first teacher as well as their therapists. It is now acknowledged that children need a private and deep special attention, they need someone to listen to and play with them on their development process. Early learning becomes a new approach on education. In recent years, the importance of early childhood era for the perception and development of the brain and the encouragement of the child by the parents are constantly stressed. What is interesting is how much responsibility the mother has in encouraging the child. Books on this subject are always warning you, saying that "You are your child's first teacher" and mother is almost solely responsible for the mental development of the child. That means, contemporary ideal of motherhood requires more efforts than in past. At those times, the main thing expected from the mother is to offer a secure environment to her child and it was considered sufficient for mother just to stay near to the child. (3)

Within the framework of contemporary motherhood, instead of questioning how much within the framework of contemporary motherhood, instead of questioning how much psychological and educational responsibility they can undertake, women take all the responsibility on themselves. When responsibilities become hard to take, if possible, women employ babysitters, private teachers etc. or feel remorse for their failure. Women, as a solution to the public pressure on them, they spend a lot of money on the courses for their children to be successful in school, to learn a foreign language or how to play an instrument. Even the old socialists and feminists, no longer want to worry about their children failure, so they send them to private schools. (3) 


\section{Outputs from the Interviews}

During the interviews with women that I conducted for my doctoral thesis, it can be clearly seen how new form of motherhood, which described above in the framework of theories and developments, takes its place in the lives of women. In this doctoral thesis (8) examining gender perceptions of two different categories of women in Turkey, it is analysed to what degree the women with certain qualities -education, financial independence, career etc. - necessity for achieving equality of which has been argued and emphasized in the literature, differ from the women who do not have such qualities in realising equality and breaking the gender-based labour division. Face-to-face semi-structured interviews were held with 26 women of middle-upper socio-cultural structure having at least a university degree, prestigious positions in work career on one hand, and 26 women of lower socio-cultural structure, maximum high-school graduate, employed in lower levels of hierarchy, on the other. This study has shown that the differences between the two categories regarding education and career do not affect the response of the women about questions related to motherhood.

The fact that women, by becoming a mother, acquire a subject status can be seen in the way that women identify themselves firstly as a mother. All of the women interviewed identify themselves "firstly mother". Six out of 52 women have no children. Only one of them has made a conscious decision not to have a child. Two of them could not have children despite receiving treatment and the other one married for one year thinks that it's too early to have a baby. One of the two single women replied the question of whether having children in the future as: "We will have one, because having a baby is a necessity". Women have children gave answers the question of how they decide to have baby like "I'm getting older, the parents insisted, my husband and I think that it is the appropriate time and no need to wait". These answers clearly indicate how the ideology settles in women's own decision-making and the women behave in accordance with the existing social framework rather than their own ideas.

Women placed within the ideological structure legitimize and endorse this structure. When women are asked the question: "Did you receive support from your partner in the first 3 years of your child?" most women told that husbands did not share the responsibilities about it. However, women seem to accept this reality and they did not show any reaction or resistance to this.

When women who said that they take support from their husbands are asked about the coverage of this support, it is understood that they talk about extremely small help like "wake up at one or two nights and feeding babies and clean them once". Similarly when they are asked "How good is your husband as a father?", almost all women answered this question like: "He is a very good father". However, statements of women about the father's responsibilities for their children indicate that women have minimum expectations to define him as a good father. Almost all women use the same expressions like "He's a good father, he plays games in the evenings and sometimes they go cinemas and parks together."

Interviewed women do not define them as "good mothers". Super-mom-woman concept that is already defined by ideology demands so much that women find it almost impossible to fulfil. However, women try so hard to achieve these responsibilities in full. The phrase that one of the women made summarizes the situation: "I'm always running around, trying but I do not keep up with anything, I'm constantly tired." The women who work all the time and take all the responsibilities cannot identify themselves as "good mothers" but on the other hand they can easily say their husbands are good fathers in return for their little efforts for the child. This shows how ideology is approved and continues without any changes in the masculine domination. Women always feel guilty for their children. The most important reason is that they never think they allocate enough time for their children because they work. The feeling of guilt is used as symbolic violence today. In this way, feeling of guilt and definitions of good women ensure the continuity of symbolic violence with its changing form. These elements which combined with the discourse of "modern woman" provide that women legitimize the ideology and get rid of the feeling of worthlessness.

\section{Conclusions}

Consequently, the ideology of motherhood was re-established using the feeling sacrifice and guilt which are inherent in it and codes of patriarchal structure were reinforced. While women -at least- have a certain level of conscious to get rid of the current domination in the past, symbolic violence and domination is being internalized by women and this conscious is being converted to acceptance through multidimensional structure of motherhood today. So, domination continues even more in a dangerous way. Motherhood ideology seems to survive without encountering any resistance.

\section{REFERENCES}

[1] Marilyn French. The War against Women, Hamish Hamilton Press, London, 1992.

[2] G. E. Andersen. The Incomplete Revolution Adapting to Women's New Roles, Polity Press, Cambridge, 2009.

[3] Rosalind Coward. Our Treacherous Hearts Why Women Let Men Get Their Way, Faber and Faber, New York, 1992.

[4] Elisabeth Badinter. The Conflict How Modern Motherhood Undermines the Status of Women, Metropolitan Books, New York, 2010. 
[5] Pierre Bourdieu. Masculine Domination, Stanford University Press, California, 2001.

[6] Terry Eagleton. Ideology an Introduction, Verso Books, London, 1986.

[7] Louis Althusser. Ideology and ideological state apparatuses,
Verso Books, London, 2010.

[8] Umut Belek Erşen, Unpublished Ph.D. Thesis, Gender Perceptions of Women from Different Social Categories in Turkey, Hacettepe University Sociology Department, Ankara, 2015. 